\title{
THE EFFECT OF COMPENSATION, LEADERSHIP AND ORGANIZATIONAL CULTURE THROUGH WORK MOTIVATION ON EMPLOYEE PERFORMANCE
}

\author{
Djoko Setyo Widodo ${ }^{{ }^{*}}$ \\ ${ }^{1}$ Krisnadwipayana University, Jakarta Timur, Indonesia \\ *djokosetyowidodo@gmail.com
}

\begin{abstract}
This study aims to examine the effect of compensation, leadership and organizational culture through work motivation on employee performance. This study uses a quantitative method by distributing questionnaires to employees in the conventional banking environment in Bekasi. The research sample is determined by simple random sampling and the technique analysis is SEM analysis with AMOS ver. 21. This study shows positive and significant results partially from the effect of variable compensation, leadership, organizational culture and motivation on employee performance. On the other hand, the study also find that organizational culture has no effect on work motivation. Based on the results of this study conclude that all hypothesis are supported but one hypotheses that examine the influence of organizational culture has no effect on work motivation.
\end{abstract}

Keywords: Compensation, Leadership, Organizational Culture, Motivation, Employee Performance

\section{INTRODUCTION}

The overall success of the institution in achieving its strategic objectives relies heavily on employee performance levels. Performance itself is the work result in quality and quantity which is met by an employee in performing its duty, according to the responsibility given to it (Mangkunegara, 2011). Meanwhile, according to Rivai and Sagala (2013) performance is a function of motivation and ability to complete the task or job someone who should have a degree of willingness and a certain level of ability. So that, it can be stated one way to make people like to work hard and improve the performance of employees is to motivate them. Organizations in this dynamic global world continue to strive to develop and motivate their employees to help achieve improved employee performance with a variety of Human Resources applications and practices. Motivation is needed as one of the employee performance indicators. High motivated employees can be expected to demonstrate optimal employee performance. A person who joins the organization of a company is required for motivation in himself.

There are various definitions of work motivation, one of which Robbins (2012) defines that motivation as a process that explains the intensity, direction, and perseverance of an individual to achieve his goals. Motivation can also be expressed as a psychological process that evokes and directs behavior toward goal-directed behavior. While Hasibuan (2013) states that the motivation of work is the provision of a driving force that creates the excitement of one's work so that they want to cooperate, work effectively, and integrated with all its efforts to achieve satisfaction.

The results of research conducted by Pinar Gungor (2011) which states that the 
motivation as a variable mediation affects the performance of employees. The results of this study also support some previous research which states that the motivation determines the work of employees on the demands of employee performance and productivity (Grant, 2008; Shahzadi, et.al., 2014; Handoyo, et.al., 2015; Nurun Nabi, Islam M, Dip TM, Hossain AA, 2017).

To realize employees who have high motivation and employee performance is also required a big role from the leadership of the organization, because the Leader as a role model in the organization, so that change must start from the top level (leader). Leadership is the backbone of organizational development because without good leadership it will be difficult to achieve organizational goals.

According to Gibson (2008) the success of the company is largely determined by the effectiveness of the success of leaders and employees of all divisions within the company. This Gibson opinion has the consequence of a demand to the company to pay more attention to critical aspects which is a critical determinant of employee performance of a leader, so that employees can achieve employee Performance employees.

In addition, organizational culture is also a determinant in an organization towards leaders determine the attitude and direction in the lead. Because as it is known organizational culture organizational culture is the basic philosophy of the organization that contains beliefs, norms, and values become the guidance of all human resources in the organization in carrying out its performance (Wibowo, 2010). Organizational culture can also be expressed as a system of shared meanings shared by its members that distinguishes organizations from other organizations (Robbins, 2012).

Research on the influence of leadership style, organizational culture, and work motivation on employee performance has been done by Widodo (2011). The results showed that there is influence of leadership style, work motivation on employee performance and research of Cahyono (2012) showed that leadership style, motivation, and organizational culture have significant influence to performance. Similarly, research conducted by Prasastono (2012); Buble, M., Juras, A., \& Matic, I. (2014); Gobal, R. \& Chowdhury, G. (2014); Khuong and Hoang (2015); Algazho and Al-Anazi, (2016) which stated that there is a positive and significant influence between leadership styles on work motivation.

In addition to leadership and organizational culture, other factors that affect employee staff motivation and performance are compensation. Compensation is very important for employees; this is because compensation is a source of income for them and their families. In addition, compensation is all income in the form of money, goods directly or indirectly received by employees in return for the given to the company (Hasibuan, 2013). Compensation also becomes a picture of an employee's social status. Appropriate compensation will also determine whether the employee will survive work or get out of work. Provision of compensation is intended so that employees can work optimally to produce optimal employee performance

Provision of compensation is very important for the company, as it reflects the organization's efforts to maintain human resources. A disadvantage if the compensation is improperly given is that the company can lose employees who have good employee performance, and the company must reimburse new qualified employees (Yahyo, et al., 2013). In addition, as well as known, compensation is all income in the form of money, goods directly or indirectly received by employees in return for services that have been given. Given the appropriate and adequate compensation can increase the motivation of work. This is according to research conducted by Prasastono (2012), Negash, R. et.al., (2014) stated that there is a positive and significant influence between compensation on work motivation.

Similarly, research on the effect of compensation on the performance of 
employees has been done a lot before, such as research conducted by Nurtjahjani (2008), Setiadi, et.al. (2016) stated that the compensation done by the company gives a significant effect on employee performance. Widyatmini and Hakim (2008) expressed the same opinion in his research, namely that the relationship between compensation and employee performance is positive, meaning the better compensation received by employees, the performance of employee employees is also getting better. This statement is also supported by Wardani (2009), Hameed, A, et.al. (2014), Oluigbo, K and Anyiam, K (2014) with similar results in their research which stated that compensation has an effect on employee performance.

Based on the previous research review, the hypothesis proposed in this study are:

$\mathrm{H}_{1}$ : There is a positive and significant effect between work motivations on employee performance.

$\mathrm{H}_{2}$ : There is a positive and significant effect between leadership on work motivation.

$\mathrm{H}_{3}$ : There is a positive and significant effect between leadership on employee performance.

$\mathrm{H}_{4}$ : There is a positive and significant effect between organizational cultures on work motivation.

$\mathrm{H}_{5}$ : There is a positive and significant effect between organizational cultures on employee performance.

$\mathrm{H}_{6}$ : There is a positive and significant effect between compensation on work motivation

$\mathrm{H}_{7}$ : There is a positive and significant effect between compensation on employee performance

\section{METHODS}

The research used descriptive research (used to analyze data by describing or describing data that has been accumulated as it is without intending to make conclusions applicable to the general and generalization. Data obtained will be analyzed and interpreted in verification research which is used to test the hypothesis in accordance with the purpose of research, verification research basically wanted to test the truth of a hypothesis implemented through data collection in the field.

Meanwhile, the data sources are primary and secondary data with data collection techniques using documentation, observation and questionnaires distributed to employees within the Banking industry of Bekasi. The research sample is determined by simple random sampling. Simple random sampling is a method of sampling from a population member by random use without regard to the strata in the population (Ridwan and Kuncoro, 2008) . While, the technique analysis is SEM analysis with AMOS ver. 21

\section{RESULTS AND DISCUSSION}

The results of data analysis using SEM analysis can be seen in Figure 1 below:

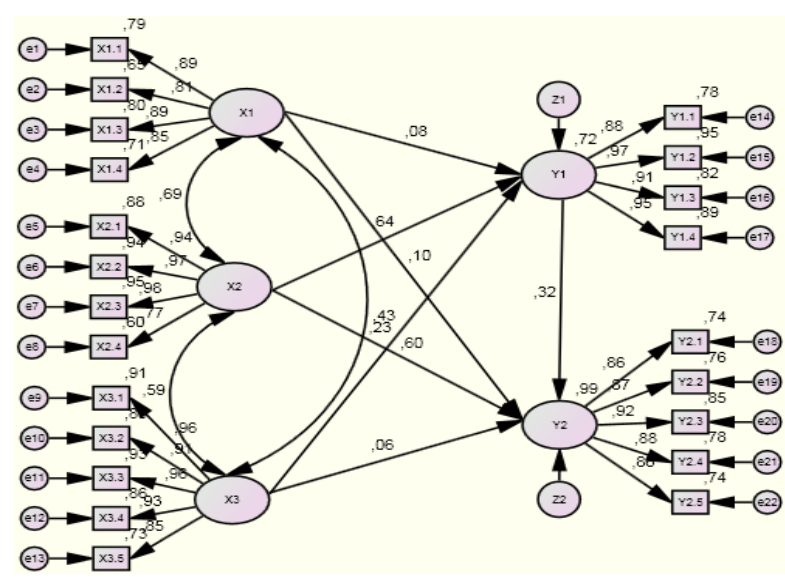

Figure1. Structural Model (2017)

Table 1. The Results of Data Analysis

\begin{tabular}{|c|c|c|c|c|}
\hline Description & $\mathbf{T}_{\mathrm{cal}}$ & Sig & Result & Conclusion \\
\hline $\mathrm{X} 1$---> Y1 & 1,152 & 0,249 & Ho Accepted & Not significant \\
\hline $\mathrm{X} 2$---> Y1 & 7,301 & $* * *$ & Ho Rejected & significant \\
\hline X3 ---> Y1 & 3,962 & $* * *$ & Ho Rejected & significant \\
\hline X1 ---> Y2 & 3,105 & 0,002 & Ho Rejected & significant \\
\hline $\mathrm{X} 2$---> Y2 & 9,122 & $* * *$ & Ho Rejected & significant \\
\hline X3 ---> Y2 & 1,961 & 0,05 & Ho Rejected & significant \\
\hline Y1 ---> Y2 & 6,683 & $* * *$ & Ho Rejected & significant \\
\hline
\end{tabular}

In the analysis of measurement models in this study showed that all variables have met the criteria of validity and reliability, while in the structural model analysis obtained that hypothesis 1-4 supports the proposed hypothesis. While for testing the 
second hypothesis (H2) precisely on $\mathrm{H} 2.1$ due to not significant then it does not support the proposed hypothesis statement.

The results of this study indicate that there is influence both simultaneously and partially from organizational culture, Leadership and Compensation against Employee Performance in Bekasi Banking, with Value $t$ arithmetic Organizational culture (X1) on Employee Performance (Y2) is 3.105 and Sig. 0,002. Since the Sig value is smaller than $\alpha(0.05)$, then Ho4 is rejected, meaning Organizational culture (X1) has a significant influence on Employee Performance (Y2). The value of $t$ arithmetic Leadership (X2) on Employee Performance (Y2) is 9,122 and Sig. 0,000. Because the Sig value is smaller than $\alpha(0.05)$, then Ho5 is rejected, meaning Leadership (X2) has a significant influence on Employee Performance (Y2). The value of $t$ Compensation (X3) on Employee Performance (Y2) is 1.961 and the value of Sig. 0.050. Since the Sig value is equal to $\alpha$ (0.05), then Ho6 is rejected, it means Compensation (X3) has a significant effect on Employee Performance (Y2).

This is in accordance with the results of research conducted by Widodo (2011). Indicating that there is influence of leadership style, work motivation to employee performance and research Cahyono (2012) shows that leadership style, motivation, and organizational culture have significant influence to performance. Similarly Wardani (2009), Hameed, A, et.al. (2014), Oluigbo, K and Anyiam, K (2014) with the same results in his research which states that the compensation has an influence on the performance of employees

Some of the findings of this research are expected to contribute to the development of leadership style theory and its implementation, both for the leaders and the lower level in Bekasi Banking. The results of this study indicate that there is influence of Leadership and Compensation against Work Motivation in Bekasi Banking, with value $t$ arithmetic Leadership (X2) to work motivation (Y1) is 7,301 and Sig value.
0,000 . Because the Sig value is smaller than $\alpha$ (0.05), then $\mathrm{Ho} 2$ is rejected, meaning Leadership (X2) has significant influence on work motivation (Y1). The value of $t$ compensation (X3) to work motivation (Y1) is 3.962 and the value of Sig. 0,000. Because the Sig value is smaller than $\alpha(0.05)$, then Ho3 is rejected, it means compensation (X3) has significant influence on work motivation (Y1). However, for organizational culture found no effect on the motivation of work in the Banking of Bekasi. It can be seen from the value t arithmetic Organizational culture (X1) to work motivation (Y1) is 1.152 and the value of Sig. 0.249. Since the Sig value is greater than $\alpha(0.05)$, then Hol is accepted, meaning organizational culture (X1) has no significant effect on work motivation (Y1).

Work motivation will be effective in Bekasi Banking if there is confidence in subordinate that driven that with the achievement of organizational goals then personal goals will also be also achieved. Motivation of work is a process of linkage between business and the satisfaction of certain needs. Internal circumstances are the needs of a person who causes certain outcomes to be attractive, meaning an unsatisfied need creates tension which in turn leads to work motivation in a person, (Hasibuan, 2013), where the work motivation is influenced by various factors. Factors affecting work motivation need to be analyzed more deeply, so that will get an idea of what factors influence it.

The analysis shows that there is influence of Leadership and Compensation to work motivation in Bekasi Banking. Although organizational culture has no significant effect on work motivation in Bekasi Banking, but the contribution of these three factors to work motivation of $17.9 \%$ indicates that there are still other dominant factors that influence work motivation. This is in line with research conducted by Prasastono (2012), Buble, M., Juras, A., \& Matic, I. (2014); Gobal, R. \& Chowdhury, G. (2014); Khuong and Hoang (2015); Algazho and Al-Anazi, (2016) that stated that there is a positive and significant influence between 
leadership and compensation on work motivation.

The results of this study indicate that there is work motivation on employee performance in Bekasi Banking with value $t$ arithmetic Working motivation (Y1) on Employee Performance (Y2) is 6,683 and Sig value. 0,000 . Since the value of Sig is smaller than $\alpha(0,05), \mathrm{Ho} 7$ is rejected, meaning that work motivation (Y1) has significant influence on employee performance (Y2).

Research conducted by Pinar Gungor (2011) which states that motivation as a variable mediation affects the performance of employees. The results of this study also support some previous research which states that the motivation determines the work of employees on the demands of employee performance and productivity (Grant, 2008, Shahzadi, et.al., 2014; Handoyo, et.al., 2015; Nurun Nabi, Islam M, Dip TM, Hossain AA, 2017).

\section{Conclusions}

Based on the research results can be concluded, that to improve the performance of employees can be done by increasing the motivation of work, provide appropriate compensation and play a leadership role. Leadership is the backbone of organizational development because without good leadership it will be difficult to achieve organizational goals. On the other hand, to realize the motivation of work required appropriate compensation. This can be realized through efforts based on the company's policy towards all employees and efforts to improve their welfare such as holiday allowance and pension. However, to realize the performance of employees was not only through the effort to play a leadership role, because exemplary leadership alone is not enough to stimulate employee performance employees. From the results of testing the relationship is not directly found that the performance of employees will be realized if employees in the organization have a strong work motivation in the organization where he works. Leadership role of a leader can affect the motivation of work, which ultimately can affect the performance of employees. Thus, it can be deduced if compensation and leadership are not able to realize employee work motivation, it will not affect the improvement of employee performance.

Based on the conclusions, can be recommended some suggestions, namely: (1) Giving appropriate compensation to improve work motivation in completing each task related to the orientation of society, (2) Often hold meetings or briefings in order to evaluate employees to work to provide better services to the community as one form of good employee performance, and monitoring the constraints during the work, the errors are emphasized not to be repeated again in time which will come, and (3) Management team as the leader needs to make various approaches to subordinates to participate in improving work motivation and apply leadership style in accordance with existing organizational culture.

\section{REFERENCES}

Algazho and Al-Anazi, (2016), The Impact of Leadership Style on Employee's Motivation, International Journal of Economics and Business Administration Vol. 2, No. 5, 2016, pp. 37-44http://www.aiscience.org/journal/ ijeba ISSN: 2381-7356 (Print); ISSN: 2381-7364 (Online)

Buble, M., Juras, A., \& Matic, I., (2014). The Relationship between Managers' Leadership Styles and Motivation. Retrieved on July 20, 2015 from https://www.efst.hr/management/Vol19 No1-2014/7- Buble_Juras_Matic.pdf

Cahyono, A., (2012), Analisa Pengaruh Kepemimpinan, Motivasi dan Budaya Organisasi Terhadap Kinerja Dosen dan Karyawan di Universitas Pawyatan Daha Kediri. Jurnal Ilmu Manajemen REVITALISASI, Vol.1. 
Gibson, (2008), Manajemen Sumber Daya Manusia. Edisi Keempat. Erlangga. Jakarta

Grant, A. M., (2008), Does intrinsic motivation fuel the pro-social fire? Motivational synergy in predicting persistence, performance, and productivity. Journal of Applied Psychology, 93, 48-58.

Gobal, R. \& Chowdhury, G., (2014). Leadership Styles and Employee Motivation: An Empirical Investigation in a Leading Oil Company in India. International journal of research in business management, 2 (5) pp. 1-10.

Gunor, P., (2011), The Relationship between Reward Management System and Employee Performance with the Mediating Role of Motivation: A Quantitative Study on Global Banks. Procedia Social and Behavioral Sciences 24 (2011) 1510-1520

Hameed, A, et.al., (2014), Impact of Compensation on Employee Performance (Empirical Evidence from Banking Sector of Pakistan), International Journal of Business and Social Science Vol. 5 No. 2

Handoyo, et.al, (2015), The Influence Of Leadership Styles On Employee's Performance Through Work Motivation (An Organizational Study at Four Hotels in Malang), Jurnal Administrasi Bisnis (JAB)|Vol. 22 No. 1 Mei 2015

Hasibuan, M. S.P., (2013), Manajemen Sumber Daya Manusia. Bumi Aksara. Jakarta

Khuong, M.N. and Hoang, D.T., (2015), The Effects of Leadership Styles on Employee Motivation in Auditing Companies in Ho Chi Minh City, Vietnam, International Journal of Trade, Economics and Finance, Vol. 6, No. 4, August 2015
Kuvaas, B. nd Dysvik, A., (2009). Perceived Investment in Employee Development, Intrinsic Motivation and Work Performance. Human Resource Management Journal, 19(3), pp. 217-236.

Mangkunegara, A. P., (2011), Manajemen Sumber Daya Manusia. PT. Remaja Rosdakarya, Bandung

Negash, R. et.al., (2014), The effect of compensation on employees motivation: In Jimma University academic staff, Basic Research Journal of Business Management and Accounts ISSN 2315-6899 Vol. 3(2) pp. 17-27

Nurtjahjani, Fullchis, (2008). Pengaruh kompensasi terhadap kinerja karyawan di PT PLN (persero) APJ malang. Jurnal administrasi dan bisnis, volume 2, nomor 1, ISSN 1987-726X

Nurun Nabi, Islam M, Dip TM, Hossain AA (2017), Impact of Motivation on Employee Performances: A Case Study of Karmasangsthan Bank Limited, Bangladesh. Arabian J Bus Manag Review 7: 293.

Oluigbo, K and Anyiam, K., (2014), The Role Of Compensation On Employee Performance In An Information Technology Organization, International Journal of Research in Information Technology (IJRIT), Vol 2, Issue \$.

Prasastono, N., (2012), Pengaruh gaya kepemimpinan dan kompensasi terhadap motivasi kerja karyawan hotel muria semarang. Jurnal Dinamika Kepariwisataan Vol. XI No. 2

Ridwan dan Kuncoro, (2008). Análisis jalur (Path Análisis),. Edisi kedua. Penerbit Alfabeta: Bandung

Robbins, S.P., (2012), Perilaku Organisasi. Indeks, Jakarta 
Setiadi, R.U., et.al., (2016), The Effect of Compensation and Work Motivation on Employee Performance at Semen Indonesia Limited Company, International Journal of Academic Research and Reflection Vol. 4, No. 3, 2016 ISSN 2309-0405

Shahzadi, I, et.al., (2014), Impact of Employee Motivation on Employee Performance, European Journal of Business and Management, ISSN 2222-1905 (Paper) ISSN 2222-2839 (Online), Vol. 6 No. 23

Wardani, Eka. (2009). Pengaruh kompensasi, keahlian dan motivasi Kerja terhadap prestasi kerja karyawan Pada PT. Pembangkitan jawa bali Unit pembangkitan Muara Tawar. Jurnal Manajemen 2009. Fakultas Ekonomi, Jurusan Manajemen Universitas Gunadarma
Wibowo, (2010). Budaya Organisasi. Rajawali Pers: Jakarta

Widodo, (2011). Pengaruh Gaya Kepemimpinan, Budaya Organisasi,dan Motivasi Kerja Terhadap Kinerja Guru. Jurnal Pendidikan Penabur

Widyatmini, L. H., (2008), Hubungan Kepemimpinan, Kompensasi dan Kompetensi Terhadap Kinerja Pegawai Dinas Kesehatan Kota Bekasi. Jurnal Ekonomi Bisnis, Vol. 13, No. 2.

Yahyo, et al., (2013), Pengaruh Motivasi, Lingkungan Kerja, dan Kompensasi Terhadap Kinerja Karyawan Melalui semangat Kerja Karyawan (Studi Kasus Pada Karyawan Bagiam Produksi CV. Putra Jaya Sahitaguna, Semarang). Diponegoro Journal of Social and Politic. Hal: 1-12 